\title{
RANCANG BANGUN MEDIA PEMBELAJARAN BAGI MURID SEKOLAH MENENGAH PERTAMA LUAR BIASA (SMPLB) I PALANGKA RAYA
}

\section{Design and Development of Learning Media for Students of Extraordinary Ist High School I Palangka Raya}

\section{Putu Bagus Adidyana Anugrah Putra* \\ Viktor Handrianus Pranata Wijaya}

\section{Admi Ruth Sinana}

Universitas Palangka Raya, Palangka Raya, Central Kalimantan, Indonesia

*email: putubagus@it.upr.ac.id

\begin{abstract}
Abstrak
Ilmu pengetahuan dan teknologi berkembang dengan sangat pesat, salah satunya pada bidang aplikasi web yang berkembang pesat karena adanya teknologi internet. Aplikasi berbasis web dapat digunakan sebagai media pembelajaran. Media pembelajaran sebagai salah satu sarana meningkatkan mutu pendidikan sangat penting dalam proses pembelajaran. Pada penelitian ini, Sekolah Luar Biasa Negeri I Palangka Raya, khususnya pada tingkat Sekolah Menengah Pertama (SMPLB) dijadikan referensi dalam pembuatan media pembelajaran. Siswa-siswi pada SMPLB merupakan siswasiswi berkebutuhan khusus. Aplikasi media pembelajaran ini ditujukan kepada siswasiswi yang memiliki keterbatasan pada pendengaran dan berbicara. Aplikasi media pembelajaran berbasis website ini dikembangkan menggunakan metode waterfall dengan tahapan analisis sistem, seperti pada pemerolehan kebutuhan data, teknologi yang digunakan pada proses bisnis dan rencana kegiatan. Data Flow Diagram (DFD) dan Entity Relationship Diagram (ERD) juga digunakan pada aplikasi ini. Desain tabel digunakan pada aplikasi ini, sementara desain navigasi menggunakan sitemap. Desain antarmuka dan implementasi dilakukan dengan bahasa pemrograman PHP. Pada tahap pengujian menggunakan blackbox testing. Media pembelajaran ini menjadi bahan ajaran tambahan dimana sisi dari visual siswa-siswi tersebut dapat digunakan langsung melihat objek pembelajaran.
\end{abstract}

\author{
Kata Kunci: \\ DFD \\ ERD \\ Media Pembelajaran \\ PHP \\ Waterfall \\ Website \\ Keywords: \\ DFD \\ $E R D$ \\ Learning Media \\ PHP \\ Waterfall \\ Website \\ Accepted \\ October 2018 \\ Published \\ December 2018

\section{PENDAHULUAN} \\ IImu pengetahuan dan teknologi mengalami \\ perkembangan yang sangat pesat, salah satunya pada \\ bidang aplikasi web yang perkembangannya semakin \\ pesat sejak munculnya teknologi internet dikarenakan \\ sangat membantu dalam kemudahan serta kecepatan \\ pengiriman, penyampaian dan penerimaan informasi.
}

\begin{abstract}
Science and technology are increasing, one of them in the field of web applications that is overgrowing because of internet technology. Web-based applications can be used as learning media. Learning media as a tool to improve the quality of education is very important in the learning process. In this research, Sekolah Luar Biasa Negeri I Palangka Raya, especially at the level of the Junior High School (SMPLB) was used as a reference in making learning media. Students at SMPLB are students with special needs. This learning media application is intended for students who deficient in the sense of hearing and speaking. This website-based learning media application was developed using the waterfall method with the stages of system analysis, such as the acquisition of data requirements, technology used in business processes and activity plans. Data Flow Diagrams (DFD) and Entity Relationship Diagrams (ERD) are also used in this application. Table design is used in this application, while navigation design uses a sitemap. Interface design and implementation are done with the PHP programming language. In the testing phase using black-box testing. This learning media is an additional teaching material where the visual side of the students can be used to see the learning object directly.
\end{abstract}

Serta internet telah menjadi hal yang tidak terpisahkan dari kebutuhan sehari-hari. Aplikasi berbasis web awalnya dibangun dengan menggunakan bahasa yang disebut HTML (Hypertext Markup Languages) kemudian dalam perkembangan berikutnya dikenal juga bahasa Pemrograman PHP (Personal Home Page) (Ngafifi, 20I4). 
Di sisi lain media pembelajaran sebagai salah satu sarana meningkatkan mutu pendidikan sangat penting dalam proses pembelajaran. Ada beberapa alasan, mengapa media pendidikan dapat mempertinggi prestasi belajar siswa (Miftahurrizqi \& Masroah, 2017). Alasan berkenaan dengan manfaat media pendidikan adalah pengajaran akan lebih menarik perhatian siswa sehingga dapat menumbuhkan motivasi belajar siswa (Rahmaniati, 20I5). Selain itu bahan pengajaran akan lebih jelas maknanya sehingga dapat lebih dipahami oleh para siswa, dan memungkinkan siswa menguasai tujuan pengajaran lebih baik, metode mengajar akan lebih bervariasi, tidak semata-mata komunikasi verbal melalui penuturan kata-kata oleh guru, sehingga siswa tidak bosan dan guru tidak kehabisan tenaga, apalagi bila guru mengajar untuk setiap jam pelajaran, siswa lebih banyak melakukan kegiatan belajar, sebab tidak hanya mendengarkan uraian guru, tetapi juga aktivitas lain seperti mengamati, melakukan, mendemonstrasikan dan lain-lain (Wanti \& Haris, 20I5).

Media pendidikan dapat berupa model atau alat peraga, flowchart, tabel-tabel, dan media berbasis website (Rahmaniati et al., 2018). Khususnya pada Sekolah Luar Biasa Negeri I Palangka Raya yang merupakan sekolah satu atap terdiri dari TKLB, SDLB, SMPLB, dan SMALB (Riadin et al., 2017). Anak Berkebutuhan Khusus (ABK) yang ada di SLBN I Palangka Raya bermacam-macam, ada yang berkekurangan dalam kemampuan penglihatan, pendengaran, mental, gerak, dan ada juga siswa yang mengalami gangguan secara kompleks (Usop, 20I4).

Pada kasus ini penulis mengambil SMPLB sebagai bahan untuk dijadikan sebagai acuan pembuatan aplikasi. Dimana SMPLB sebenarnya hampir sama dengan yang biasa kita kenal dengan SMP namun karena di dalam sekolah ini yang menjadi siswa maupun siswinya berkebutuhan khusus maka disebutlah sebagai SMPLB atau Sekolah Menengah Pertama Luar Biasa dan aplikasi ini ditujukan kepada siswa dengan kebutuhan khusus yaitu dalam hal kurangnya pendengaran dan berbicara.
Seperti kita ketahui jika siswa ini lebih mengandalkan kemampuan visual karena kemampuan mendengar maupun berbicara mereka tidak dapat digunakan (Putra, 2017). Sehingga pembelajaran dengan menggunakan media pembelajaran berbasis website ini akan menjadi bahan ajaran tambahan dimana sisi dari visual siswa tersebut dapat digunakan langsung melihat objek pembelajaran tersebut dan diangkatlah permasalahan pada penelitian ini yaitu media pembelajaran bagi murid SMPLB I Palangka Raya.

Sehubungan dengan pemanfaatan website, peneliti sebelumnya juga telah melakukan penelitian untuk mengembangkan perangkat lunak generate file untuk import data ke feeder PDDIKTI (Pranatawijaya et al., 2016). Rancang bangun sistem informasi praktikum pada jurusan teknik informatika universitas palangkaraya berbasis web (Widiatry, 2017) dapat digunakan sebagai dasar dalam pembuatan otomatisasi pembuatan informasi berdasarkan data-data tertentu. Terakhir adalah analisis dan desain website monitoring konsultasi bimbingan kartu rencana studi (KRS) (Putra et al., 20I7), Pengembangan perangkat lunak generate file akun uang kuliah tunggal di Universitas Palangka Raya (Pranatawijaya et al., 2018) dan Rancang bangun sistem informasi pencarian data mahasiswa dan dosen pada Fakultas Hukum Universitas Palangka Raya (Putra et al., 2017) memberikan cara untuk pengelolaan data yang akan digunakan untuk media pembelajaran dan pemahaman dalam teknik searching data. Sehingga, tujuan penelitian ini adalah untuk mengembangkan media pembelajaran bagi murid SMPLB I Palangka Raya sehingga dapat menjadi suatu pondasi untuk mengimplementasikan sistem tersebut nantinya.

\section{METODOLOGI}

Metode Pengembangan perangkat lunak yang digunakan adalah metode Waterfall menurut Sommerville (201 I). Waterfall model adalah sebuah contoh dari proses 
perencanaan, di mana semua proses kegiatan harus terlebih dahulu direncanakan dan dijadwalkan.

\section{Studi Pustaka dan Observasi}

Metode ini melakukan studi pustaka terhadap buku, jurnal ilmiah nasional dan internasional sebagai pendukung dalam penelitian. Observasi dilakukan untuk mengambil data-data untuk titik dan berapa besar radius yang diperlukan untuk menandakan suatu ruangan yang nantinya akan dijadikan area untuk mengeluarkan informasi.

2. Analisis Sistem

Proses pencarian kebutuhan difokuskan pada software untuk mengetahui sifat dari website yang akan dibuat, pemodelan proses bisnis menggunakan Data Flow Diagram (DFD) dan Entity Relationship Diagram (ERD).

DFD merupakan diagram yang menggambarkan alir data dalam suatu entitas ke sistem atau sistem ke entitas. DFD juga dapat diartikan sebagai teknik grafis yang menggambarkan alir data dan transformasi yang digunakan sebagai perjalanan data dari input atau masukan menuju keluaran atau output.

ERD adalah diagram yang menghubungkan antar entitas di dalam penyusunan/perancangan basis data. Diagram Entitiy Relationaship ini ditemukan oleh Chen pada tahun 1976. Tujuan dari ERD adalah untuk menunjukkan objek data dan relationship yang ada pada objek tersebut

3. Desain Sistem

Proses ini digunakan untuk membuat "blueprint" software seperti, perancangan basis data dan perancangan antarmuka (interface).

4. Implementasi

Proses ini akan dilakukan pembuatan perangkat lunak sesuai dengan perancangan basis data dan antar muka yang telah dilakukan pada tahap sebelumnya.

5. Pengujian Sistem

Proses pengujian akan dilakukan dengan Blackbox Testing yang disertai dengan melakukan simulasi data. Pengujian Black Box adalah pengujian aspek fundamental sistem tanpa memperhatikan struktur logika internal perangkat lunak. Metode ini digunakan untuk mengetahui apakah perangkat lunak berfungsi dengan benar. Pengujian black box merupakan metode perancangan data uji yang didasarkan pada spesifikasi perangkat lunak. Data uji dieksekusi pada perangkat lunak dan kemudian keluar dari perangkat lunak dicek apakah telah sesuai yang diharapkan. Tujuan utama pengujian haruslah untuk mengekspos kesalahan dalam perangkat lunak dan untuk menghindari potensi kegagalan (Bhasin et al., 2014).

\section{HASIL DAN PEMBAHASAN}

Sasaran pengguna dari website media pembelajaran ini adalah guru dan siswa yang sedang menempuh pendidikan kelas VII Tunarungu, VIII Tunarungu dan IX Tunarungu di SMPLB I Palangka Raya. Terkhusus bagi kegiatan belajar mengajar dengan menggunakan buku Tema empat dari masing-masing kelas. Dimana tema empat pada kelas VII adalah Berbagai Pekerjaan, pada kelas VIII adalah Makananku Sehat dan Bergizi serta buku tema empat pada kelas IX adalah Organ Pencernaan. Pengguna yang ada pada website media pembelajaran diatur berdasarkan aturan hak akses yaitu admin dan pengunjung.

Proses modeling pada sistem yang dibuat menerjemahkan syarat kebutuhan ke sebuah perancangan software yang dapat diperkirakan sebelum dibuat coding. Proses ini terbagi menjadi 2, yaitu analisis dan desain. Pada analisis menggunakan DFD serta ERD. Pada desain akan dilakukan desain tabel, desain navigasi 
mengunakan Sitemap dan desain antarmuka/representasi interface. Tahapan ini akan menghasilkan dokumen yang disebut software requirement. Diagram Konteks menggambarkan seluruh input ke sistem atau output dari sistem.

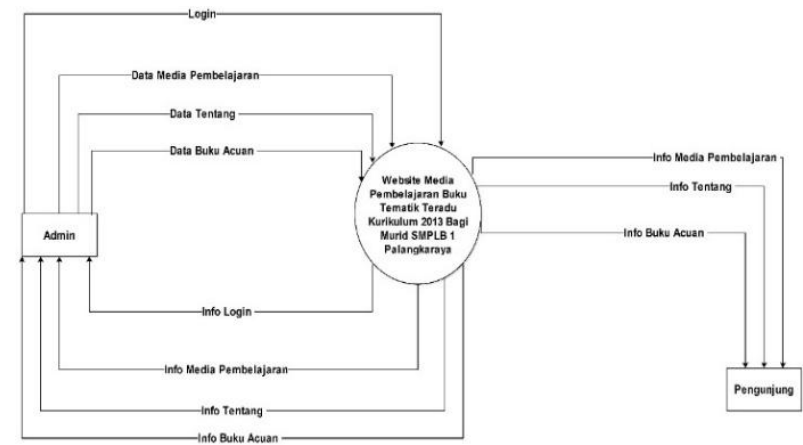

Gambar I. Diagram Konteks

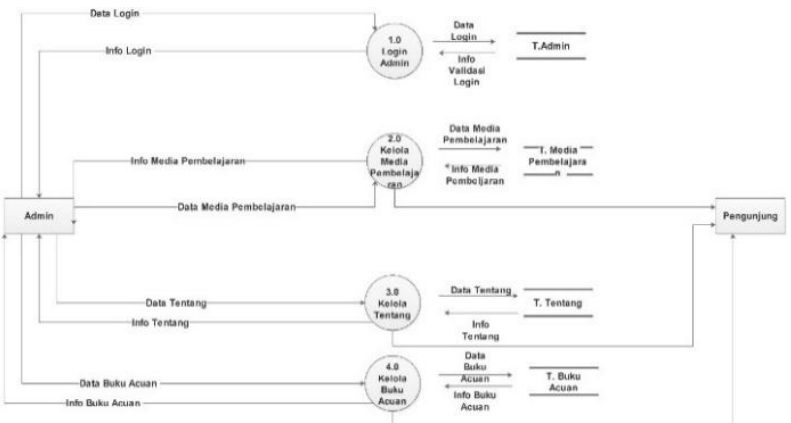

Gambar 2. DFD Level 0

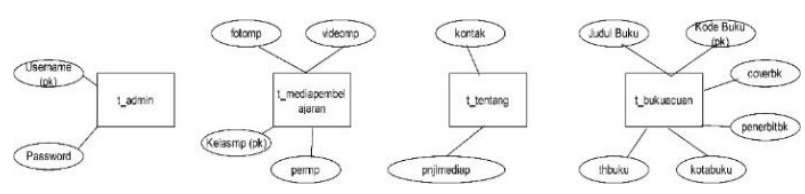

Gambar 3. ERD

Dalam merancang sitemap (peta situs), seperti kerangka website yang mengambarkan denah dari website, memuat informasi mengenai setiap halaman yang ada di dalam website.

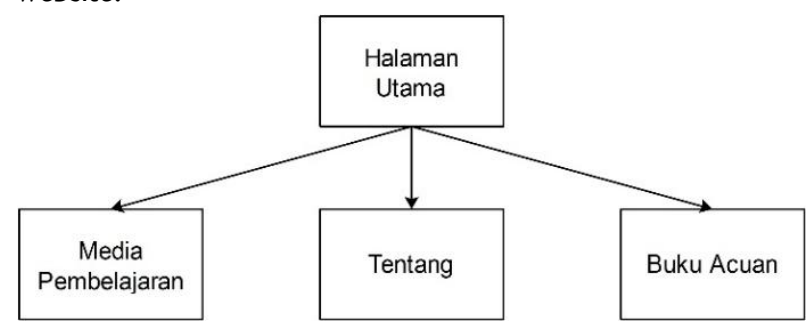

Gambar 4. Sitemap Menu Utama
Untuk perancangan antarmuka digunakan dua metode pemrograman, aplikasi server menggunakan Database MySQL dan aplikasi website menggunakan PHP.

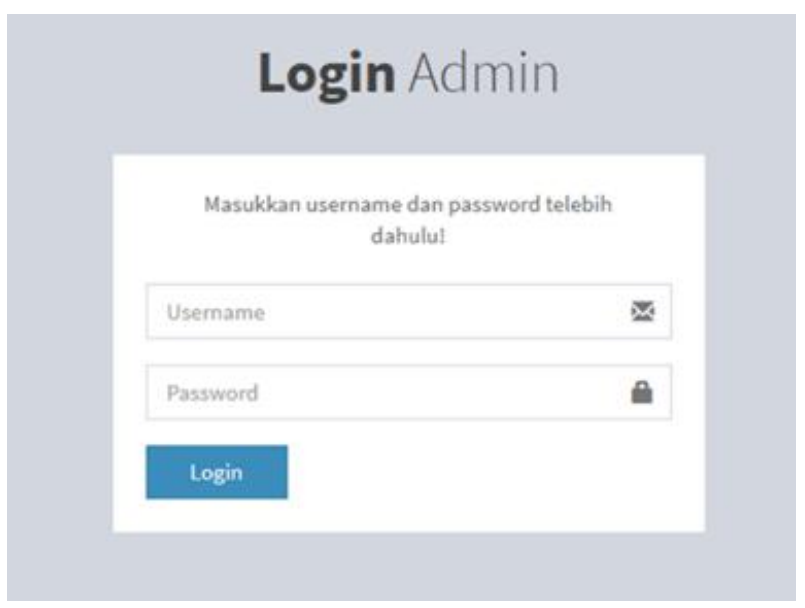

Gambar 5. Implementasi Halaman Login

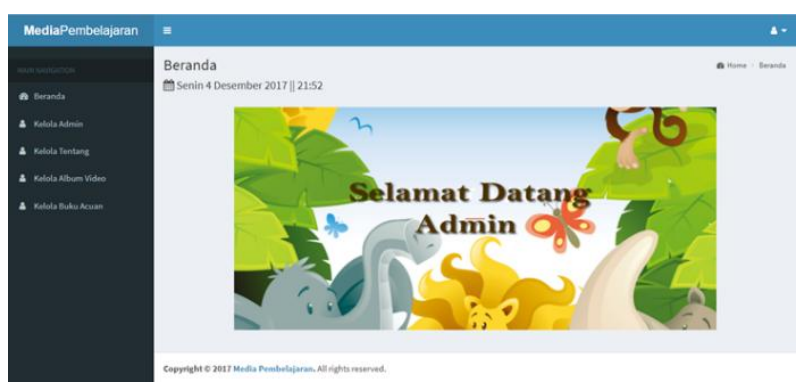

Gambar 6. Implementasi Beranda Admin

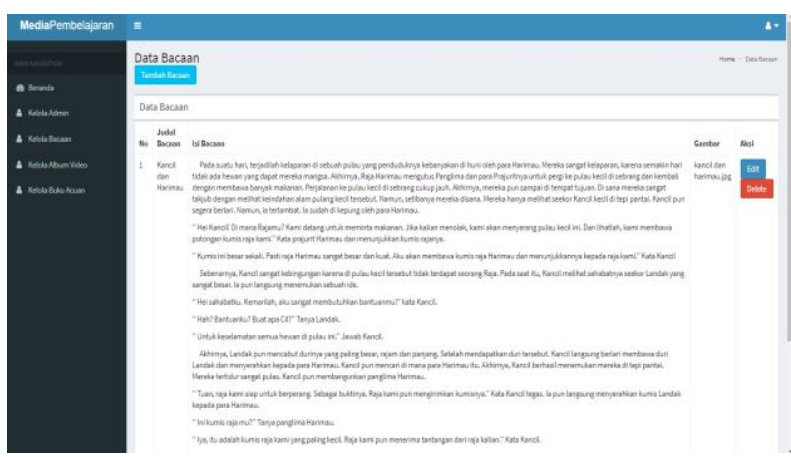

Gambar 7. Implementasi Halaman Kelola Bacaan

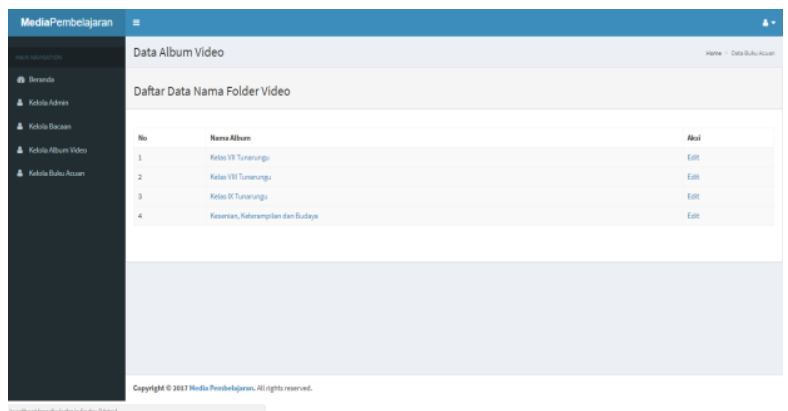

Gambar 8. Implementasi Halaman Data Album Video 


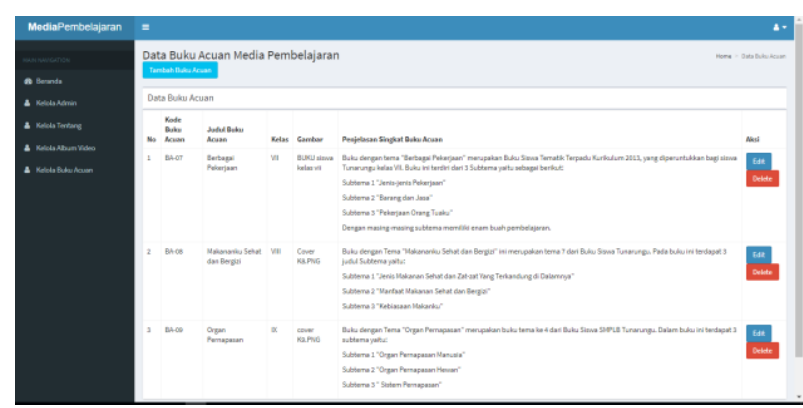

Gambar 9. Implementasi Halaman Buku Acuan
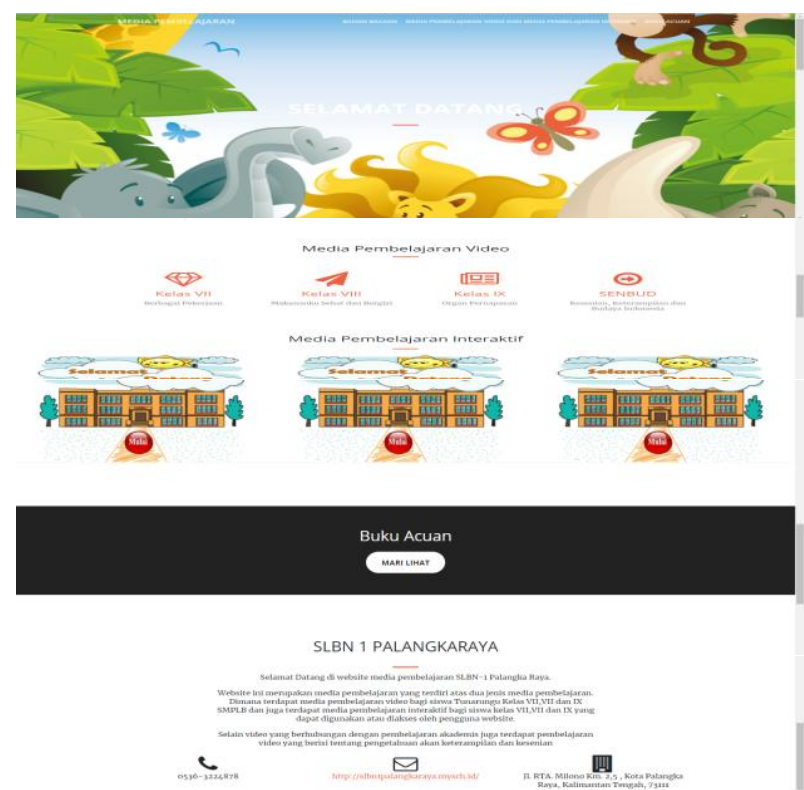

Gambar I0. Implementasi Halaman Beranda

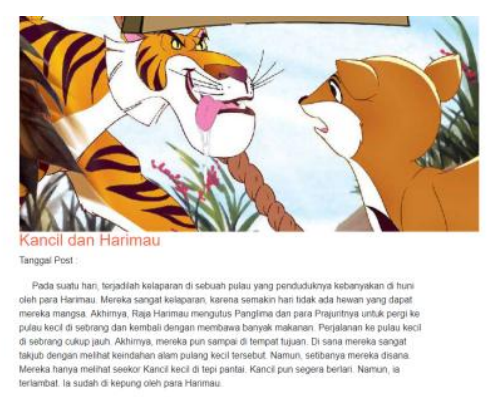

Gambar I I. Implementasi Halaman Bacaan

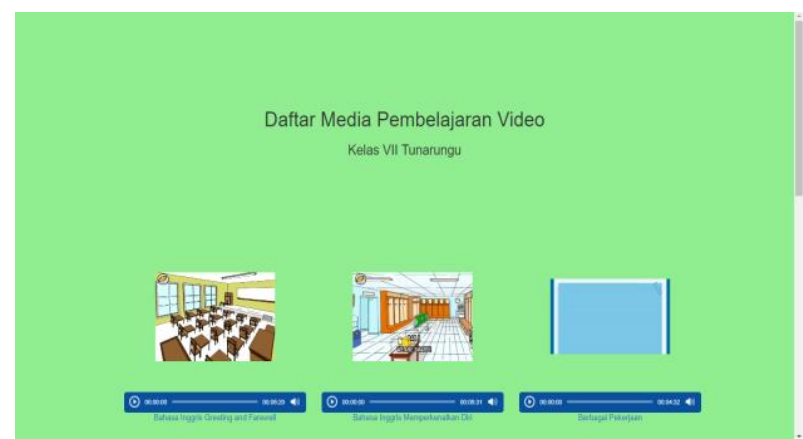

Gambar I 2. Implementasi Halaman Media Pembelajaran Video

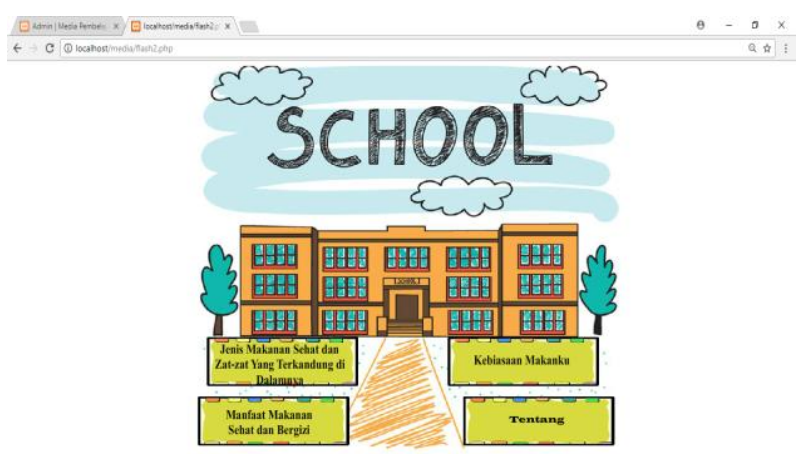

Gambar I3. Implementasi Halaman Media Pembelajaran Interaktif

Setelah melakukan implementasi, dilakukan pengujian terhadap sistem dengan tujuan untuk melihat semua kesalahan dan kekurangan yang ada pada sistem. Pengujian sistem pada website profil ini dilakukan dengan menggunakan metode Black Box. Pada pengujian ini fokus pada kebutuhan fungsional dan luarannya sesuai dengan yang diharapkan atau sebaliknya, sebagaimana disajikan pada Tabel I berikut.

Tabel I. Hasil Analisa Proksimat Maggot dan Tepungnya

\begin{tabular}{|c|c|c|c|c|}
\hline No & $\begin{array}{c}\text { Kondisi } \\
\text { Awal }\end{array}$ & $\begin{array}{l}\text { Hal yang } \\
\text { dilakukan }\end{array}$ & $\begin{array}{c}\text { Hasil } \\
\text { Keluaran }\end{array}$ & Hasil \\
\hline$I$ & $\begin{array}{l}\text { Admin } \\
\text { mengunjungi } \\
\text { halaman } \\
\text { kelola admin. }\end{array}$ & $\begin{array}{l}\text { Admin } \\
\text { mengubah } \\
\text { data } \\
\text { username dan } \\
\text { password } \\
\text { admin. }\end{array}$ & $\begin{array}{l}\text { Data } \\
\text { username dan } \\
\text { password } \\
\text { admin berhasil } \\
\text { diubah. }\end{array}$ & OK \\
\hline 2 & $\begin{array}{l}\text { Admin } \\
\text { mengunjungi } \\
\text { halaman } \\
\text { kelola } \\
\text { bacaan }\end{array}$ & $\begin{array}{l}\text { Admin } \\
\text { menambah } \\
\text { data bacaan } \\
\text { Admin } \\
\text { mengubah } \\
\text { data bacaan } \\
\text { Admin } \\
\text { menghapus } \\
\text { data bacaan }\end{array}$ & $\begin{array}{l}\text { Data bacaan } \\
\text { berhasil } \\
\text { ditambah. } \\
\text { Data bacaan } \\
\text { berhasil diubah } \\
\text { Data bacaan } \\
\text { berhasil di } \\
\text { hapus }\end{array}$ & OK \\
\hline 3 & $\begin{array}{l}\text { Admin } \\
\text { mengunjungi } \\
\text { halaman } \\
\text { media } \\
\text { pembelajaran } \\
\text { video }\end{array}$ & $\begin{array}{l}\text { Admin } \\
\text { mengubah } \\
\text { data album } \\
\text { video } \\
\text { Admin } \\
\text { menambah } \\
\text { data video } \\
\text { Admin } \\
\text { mengubah } \\
\text { data video } \\
\text { Admin } \\
\text { menghapus } \\
\text { data video }\end{array}$ & $\begin{array}{l}\text { Data album } \\
\text { video berhasil } \\
\text { di ubah } \\
\text { Data video } \\
\text { berhasil } \\
\text { ditambah } \\
\text { Data video } \\
\text { berhasil di } \\
\text { ubah } \\
\text { Data video } \\
\text { berhasil } \\
\text { dihapus }\end{array}$ & OK \\
\hline 4 & $\begin{array}{l}\text { Admin } \\
\text { mengunjungi } \\
\text { halaman } \\
\text { kelola buku } \\
\text { acuan }\end{array}$ & $\begin{array}{l}\text { Admin } \\
\text { menambah } \\
\text { data buku } \\
\text { acuan } \\
\text { Admin } \\
\text { mengubah }\end{array}$ & $\begin{array}{l}\text { Data buku } \\
\text { acuan berhasil } \\
\text { ditambah. } \\
\text { Data buku } \\
\text { acuan berhasil } \\
\text { diubah }\end{array}$ & OK \\
\hline
\end{tabular}




\begin{tabular}{|c|c|c|c|}
\hline & & $\begin{array}{l}\text { data buku } \\
\text { acuan } \\
\text { Admin } \\
\text { menghapus } \\
\text { data buku } \\
\text { acuan }\end{array}$ & $\begin{array}{l}\text { Data buku } \\
\text { acuan berhasil } \\
\text { dihapus. }\end{array}$ \\
\hline 5 & $\begin{array}{l}\text { Admin } \\
\text { mengklik } \\
\text { button } \\
\text { logout. }\end{array}$ & $\begin{array}{l}\text { Admin logout } \\
\text { dari halaman } \\
\text { admin. }\end{array}$ & $\begin{array}{l}\text { Admin berhasil } \\
\text { logout dan } \\
\text { diarahkan ke } \\
\text { halaman } \\
\text { website } \\
\text { pengunjung. }\end{array}$ \\
\hline
\end{tabular}

\section{KESIMPULAN}

Dalam merancang bangun Media Pembelajaran Bagi Siswa SMPLB I Palangka Raya Berbasis Website digunakan metode pengembangan perangkat lunak Waterfall yang terdiri atas lima tahapan yaitu requirement definition, system and software design, implementation and unit testing, integration and system setting, dan operation and maintenance. Untuk tahapan model development yang merupakan tahapan untuk memodelkan seluruh proses yang ada menggunakan DFD yang meliputi process requirement, Diagram Konteks, DFD per-level, dan ERD. Media pembelajaran ini dibangun dengan aplikasi Netbeans sebagai editor PHP, SQLyog sebagai pengolah database, dan XAMPP sebagai web server. Metode pengujian yang dilakukan pada website adalah Blackbox. Untuk pengembangan kedepannya diharapkan website ini dapat memiliki hak akses baru yaitu bagi setiap guru, sehingga untuk menambahkan media pembelajaran video, ebook, dan media lainnya juga dapat dilakukan oleh masing-masing guru.

\section{REFERENSI}

Bhasin, H., Khanna, E., \& Sudha, S. 2014. Black Box Testing based on Requirement Analysis and Design Specifications. International Journal of Computer Applications. 87(18):36-40.

Miftahurrizqi \& Masroah. 2017. Penggunaan Media Objek untuk Meningkatkan Hasil Belajar IPA Peserta Didik. Bitnet: Jurnal Pendidikan Teknologi Informasi. 2(I): I4-19.

Ngafifi, M. 2014. Kemajuan Teknologi dan Pola Hidup Manusia dalam Perspektif Sosial Budaya. Jurnal Pembangunan Pendidikan: Fondasi dan Aplikasi. 2(I):33-47.
Pranatawijaya, V.H., Putra, P.B.A.A., \& Gunawan, V.A. 2016. Pengembangan Perangkat Lunak Generate File Untuk Migrasi Data EPSBED Ke Format Table Feeder PDDIKTI. Jurnal Saintekom: Sains, Teknologi, Komputer dan Manajemen. 6(2): I-II.

Pranatawijaya, V.H., Putra, P.B.A.A., Widiatry, \& Sari, N.N.K. 2018. Pengembangan Perangkat Lunak Generate File Akun Uang Kuliah Tunggal (UKT) Universitas Palangka Raya. Jurnal Saintekom: Sains, Teknologi, Komputer dan Manajemen. 8(2): I66-I78.

Putra, C.A. 2017. Pemanfaatan Teknologi Gadget Sebagai Media Pembelajaran. Bitnet: Jurnal Pendidikan Teknologi Informasi. 2(2): I- I0.

Putra, P.B.A.A., Sari, N.N.K., Pranatawijaya, V.H. 2017. Analisis dan Desain Website Monitoring Konsultasi Bimbingan Kartu Rencana Studi (KRS). Jurnal Teknologi Informasi. I I ( I):58-68.

Putra, P.B.A.A., Pranatawijaya, V.H., Widiatry, \& Lisa. 2017. Rancang Bangun Sistem Informasi Pencarian Data Mahasiswa dan Dosen pada Fakultas Hukum Universitas Palangka Raya. Jurnal Teknologi Informasi. I I(2):36-45.

Rahmaniati, R. 20I5. Keterampilan Calon Guru SD Dalam Menerapkan Media Pembelajaran IPA Berbasis IT Terhadap Hasil Belajar Siswa SDN-5 Panarung Palangka Raya. Anterior Jurnal. I5(I):62-69.

Rahmaniati, R., Bulkani, B., \& Pujianti, F. 2018. Model Pembelajaran Scramble menggunakan Media Wayang Pahlawan untuk Meningkatkan Hasil Belajar IPS Peserta Didik Kelas V-A SDN I Sabaru Palangka Raya. Anterior Jurnal. I7(2):79-85.

Riadin, A., Misyanto, M., \& Usop, D.S. 2017. Karakteristik Anak Berkebutuhan Khusus di Sekolah Dasar Negeri (Inklusi) di Kota Palangka Raya. Anterior Jurnal. 17(I):22-27.

Sommerville, I. 20II. Software Engineering. 9th Edition. New Jersey: Pearson Education.

Usop, D.S. 2014. Model Pendidikan yang Diberikan oleh Guru pada Anak Autis di SLB Negeri I Palangka Raya. Anterior Jurnal. 13(2): 198-204.

Wanti, A.S.W. \& Haris, H. 20I5. Peranan Media Gambar (Visual) dalam Meningkatkan Konsentrasi Belajar Siswa pada Mata Pelajaran PKN di SMPN I Sungguminasa Kabupaten Gowa. Jurnal Tomalebbi. 2(2):29-34. 
Widiatry. 2017. Rancang Bangun Website Sistem Informasi Praktikum pada Jurusan Teknik Informatika Univeritas Palangka Raya. Jurnal Teknologi Informasi. I I (I):76-85. 